\title{
New data on Jurassic Sinoalidae from northeastern China (Insecta, Hemiptera)
}

\author{
Jun Chen, ${ }^{1,2}$ Yan Zheng, ${ }^{1}$ Guangjin Wei, ${ }^{1}$ and Xiaoli Wang ${ }^{1}$ \\ ${ }^{1}$ Institute of Geology and Paleontology, Linyi University, Shuangling Road, Linyi 276000, China $\langle$ rubiscada@ sina.com $\rangle$, \\ 〈zhengyan536@lyu.edu.cn〉,〈weiguangjin@lyu.edu.cn〉,〈wangxiaoli@lyu.edu.cn〉 \\ ${ }^{2}$ State Key Laboratory of Palaeobiology and Stratigraphy, Nanjing Institute of Geology and Palaeontology, Chinese Academy of Sciences, \\ 39 East Beijing Road, Nanjing 210008, China
}

\begin{abstract}
The Sinoalidae, as one of the three Mesozoic froghopper families, was recently recognized from the latest Middle-earliest Late Jurassic Daohugou Biota of northeastern China. We herein report some new materials from the same horizon and locality, providing some new insights on morphological diversity and evolution of this family. Shufania hani new genus new species indicates that the relative branching position of veins $\mathrm{M}$ and $\mathrm{CuA}$ of the forewing is highly variable within the Sinoalidae and not appropriate for family-level diagnosis. The venations of three reported sinoalid hind wings are conservative, likely due to its simplified topology and reduced terminal branches. Color patterns of hind wings are likely variable for different sinoalid froghoppers. However, considering that color pattern is easily weakened or even erased by diagenetic processes for imprint fossils, the morphological character is not reliable for distinguishing different sinoalid taxa. Additionally, our new material suggests that the number of lateral spines of the hind tibia can vary intra-individually for sinoalids, just as in some recent froghoppers.
\end{abstract}

\section{Introduction}

The hemipteran superfamily Cercopoidea Leach, 1815, known as froghoppers or spittlebugs, comprises nearly 3000 described species. The high-level classification of living Cercopoidea is still controversial: five modern cercopoid families (Cercopidae Leach, 1815, Aphrophoridae Amyot and Serville, 1843, Clastopteridae Dohrn, 1859, Machaerotidae Stål, 1866, and Epipygidae Hamilton, 2001) have been described to date, but various taxonomists recognize three to five (Hamilton, 2001, 2012; Dietrich, 2002, 2005; Holzinger et al., 2003). Moreover, three extinct families from the Mesozoic have been attributed to this superfamily (Wang et al., 2012; Chen et al., 2015a).

The family Procercopidae Handlirsch, 1906, recorded from the Early Jurassic to Early Cretaceous in Germany, Russia, Central Asia, Southeast Asia, and China, is widely accepted as the stem group of cercopoids (Shcherbakov and Popov, 2002; Chen et al., 2015a). Representatives of the extinct froghopper families Sinoalidae Wang and Szwedo in Wang et al., 2012 and Cercopionidae Hamilton, 1990 were exclusively known from the Jurassic deposits in northeastern China and the Early Cretaceous of Brazil, respectively (Hamilton, 1990; Wang et al., 2012). By the mid-Cretaceous, primitive cercopoids became extinct and ancestors of modern groups appeared and became diversified (Shcherbakov and Popov, 2002; Chen et al., 2015a).

The family Sinoalidae was erected as part of the latest Middle-earliest Late Jurassic Daohugou Biota, Inner Mongolia of China. Sinoalidae, which is closely related to early Procercopidae and shares some plesiomorphic characters with ancient Hylicelloidea, represents one of the distinct diversifications of ancestral Cercopoidea. Up to now, five genera (Luanpingia Hong, 1983, ?Hebeicercopis Hong, 1983, Huabeicercopis Hong, 1983, Sinoala Wang and Szwedo in Wang et al., 2012, and Jiania Wang and Szwedo in Wang et al., 2012) from the Jurassic deposits of northeastern China have been attributed to this distinct froghopper family (Fig. 1; Wang et al., 2012).

We herein report some fossil sinoalids from the Daohugou Biota. A new genus and species with some significant morphological traits different from known con-familial taxa is established, and the family is revised further based on the new fossil specimens.

\section{Materials and methods}

The new Mesozoic sinoalids described herein were collected from the well-known Daohugou fossil-bearing strata of northeastern China (Fig. 1; Wang, 2009). Daohugou is now considered to be one of the most important insect Lagerstätten (Rasnitsyn et al., 2006) and has yielded abundant and diverse insects (e.g., Wang and Zhang, 2011; B. Wang et al., 2013; Chen et al., 2014; Yan et al., 2014). Generally, the fossil-bearing beds at Daohugou were placed within the Jiulongshan Formation of Bathonian-Callovian (late Middle Jurassic). However, recent isotopic dating results indicated that the Daohugou beds were deposited in the geological age of 164-158 Ma (Liu et al., 2006, 2012; L. Wang et al., 2013), which is CallovianOxfordian (latest Middle-earliest Late Jurassic) according to the 


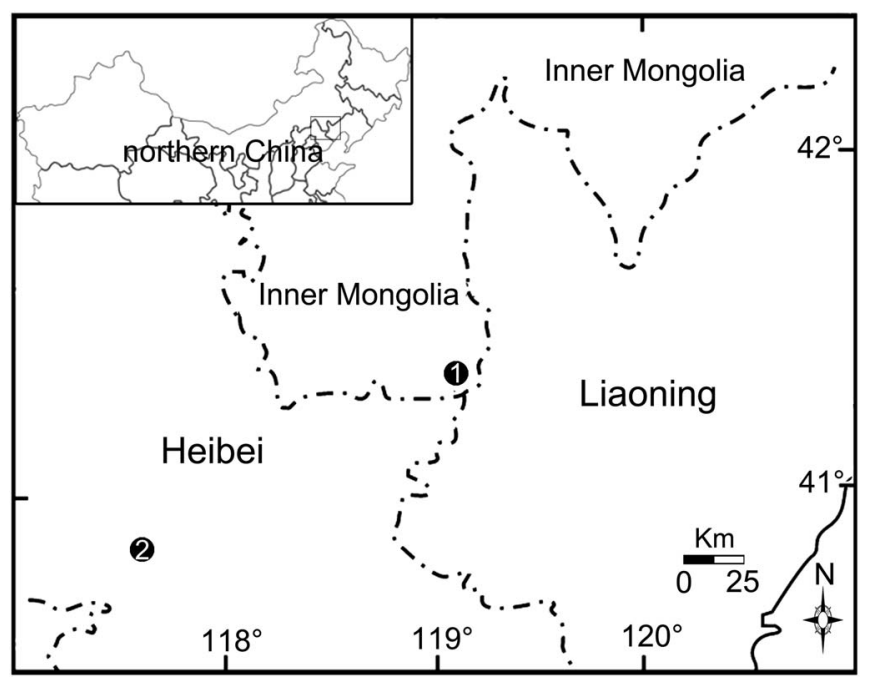

Figure 1. Locations of fossil specimens of the family Sinoalidae. 1, Daohugou, Ningcheng County, Inner Mongolia; 2, Zhouyingzi, Luangping County, Heibei.

updated International Chronostratigraphic Chart (Cohen et al., 2016).

Nel et al. (2012) proposed a new interpretation of wing venation pattern for all Paraneoptera, assuming that $\mathrm{CuA}$ gets fused with $\mathrm{M}+\mathrm{R}$ stem at the wing base and connected with $\mathrm{CuP}$ by a specialized crossvein cua-cup after its departure from $\mathrm{M}+\mathrm{R}$, which is remarkably different from the traditional interpretations. The venational terminologies used herein follow Nel et al. (2012).

The fossil sinoalids were examined dry or under alcohol, with details observed and photographed under a stereomicroscope
(ZeissSteREO Discovery V8). Line drawings were prepared with CorelDraw 12.0 and Adobe Photoshop CS3.

Repository and institutional abbreviation.-All the material and figured specimens in this study are deposited in Shandong Tianyu Museum of Nature (STMN), Pingyi, Shandong Province, China.

\section{Systematic paleontology}

Order Hemiptera Linnaeus, 1758

Suborder Cicadomorpha Evans, 1946

Superfamily Cercopoidea Leach, 1815

Family Sinoalidae Wang and Szwedo in Wang et al., 2012

Diagnosis (emended).-Forewing with apices of costal area and clavus almost at the same level; costal area and/or clavus more sclerotized and punctate and remaining parts membranous; $\mathrm{Pc}+\mathrm{CP}$ long and thicken, almost parallel to costal margin; $\mathrm{M}$ two-branched. Hind wing with $\mathrm{M}$ unbranched; crossvein $m$-cua basad of crossvein $r-m$. Three ocelli rather than two. Hind tibia with two rows of lateral spines (four at most in number for each row).

Remarks.-Our new fossil materials suggest that the relative branching position of $\mathrm{M}$ and $\mathrm{CuA}$ is variable in Sinoalidae and so not appropriate for family-level diagnosis. In addition, the fossils reported herein also provide some information on morphological diversity and evolution of hind wings and hind tibiae of the family (see Discussion).

Key to genera of the family Sinoalidae on characters of forewing (updated from Wang et al. [2012]):

1. Crossvein m-cua connecting to stem $\mathrm{M}$, bifurcation of $\mathrm{M}$ distad of apices of costal area and clavus, $\mathrm{CuA}$ branching into $\mathrm{CuA} \mathrm{A}_{1}$ and $\mathrm{Cu} \mathrm{A}_{2}$ at

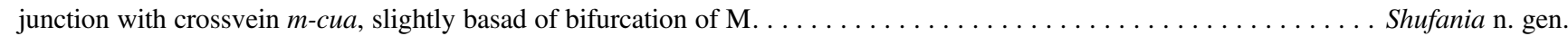
Crossvein $m$-cua absent or connecting to $\mathrm{M}_{3+4}$, bifurcation of $\mathrm{M}$ basad of apices of costal area and clavus, $\mathrm{CuA}$ branching into CuA $\mathrm{A}_{1}$ and $\mathrm{Cu} \mathrm{A}_{2}$

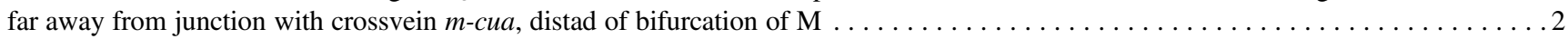

2. $\mathrm{ScP}+\mathrm{RA} \sim 1.3$ times as long as stem $\mathrm{ScP}+\mathrm{R}, \mathrm{CuA}$ forking distad of apices of costal area, stigmal cell as wide as radial cell, crossvein $m$-cua

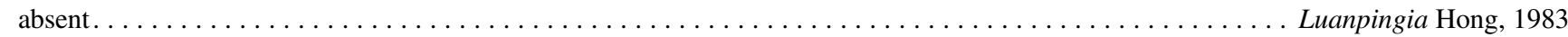

$\mathrm{ScP}+\mathrm{RA}$ at least 1.5 times as long as stem $\mathrm{ScP}+\mathrm{R}, \mathrm{CuA}$ forking basad of apices of costal area, stigmal cell about half as wide as radial cell,

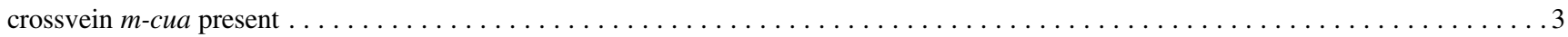

3. Apex truncate, basal cell $\sim 0.12$ times as long as forewing length, $\mathrm{ScP}+\mathrm{RA} \sim 10$ times as long as stem $\mathrm{ScP}+\mathrm{R}$, crossvein $m$-cua connecting to

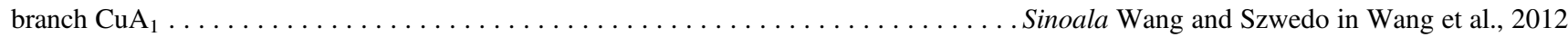
Apex rounded; basal cell long, $\mathrm{ScP}+\mathrm{RA}$ at most 4.5 times as long as stem $\mathrm{ScP}+\mathrm{R}$, crossvein $m$-cua connecting to stem $\mathrm{CuA} \ldots \ldots . \ldots 4$

4. Stems ScP, R, M and CuA leaving basal cell at common point, branch $\mathrm{ScP}+\mathrm{RA} \sim 4.4$ times as long as $\mathrm{ScP}+\mathrm{R}$. . . Huabeicercopis Hong, 1983 Common stalk $\mathrm{ScP}+\mathrm{R}+\mathrm{M}$ existing, branch $\mathrm{ScP}+\mathrm{RA} \sim 1.5$ times as long as $\mathrm{ScP}+\mathrm{R} \ldots$. . Jiania Wang and Szwedo in Wang et al., 2012

\section{Genus Shufania new genus}

Type species.-Shufania hani n. gen. n. sp., by present designation and monotypy.

Diagnosis.-As for the type species.
Etymology.-The generic name, Shufania, a feminine noun derived after Prof. Shufan Han, a well-known artist and the curator of the Museum of Linyi University. 

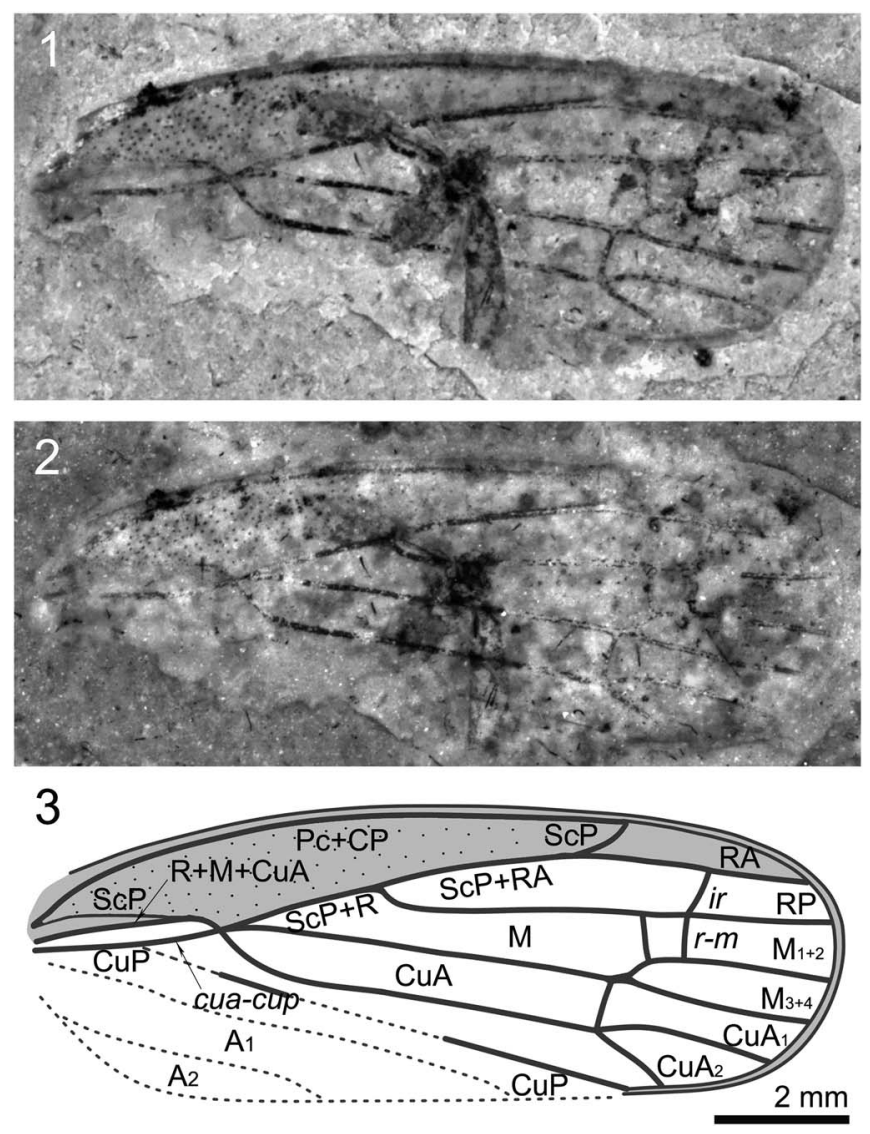

Figure 2. Shufania hani n. gen. n. sp.: (1) holotype STMN48-1807; (2) holotype under alcohol; (3) illustration of holotype. Scale bar for all images.

Holotype.-STMN48-1807, sex unknown, a sole forewing with clavus missing.

Diagnosis.-Forewing small, basal cell long, about one-fourth as long as forewing length; $\mathrm{ScP}+\mathrm{R}+\mathrm{M}+\mathrm{CuA}$ bifurcating into $\mathrm{ScP}+\mathrm{R}+\mathrm{M}$ and $\mathrm{CuA}$ at junction with crossvein cua-cup stem $\mathrm{ScP}+\mathrm{R}+\mathrm{M}$ extremely short; $\mathrm{ScP}+\mathrm{RA} \sim 1.5$ times as long as stem $\mathrm{ScP}+\mathrm{R}$; base of RP strongly curved; $\mathrm{M}$ very long and nearly straight, branched into $\mathrm{M}_{1+2}$ and $\mathrm{M}_{3+4}$ at about basal 0.75 wing length; crossvein $m$-cua connecting to stem $\mathrm{M}$ basad of bifurcation of $\mathrm{M} ; \mathrm{CuA}$ branching into $\mathrm{CuA}_{1}$ and $\mathrm{CuA}_{2}$ at junction with crossvein $m$-cua, slightly basad of bifurcation of $\mathrm{M}$.

Occurrence.-This specimen was collected from Daohugou Village $\left(41^{\circ} 18^{\prime} \mathrm{N}, 119^{\circ} 13^{\prime} \mathrm{E}\right)$, Shantou Township, Ningcheng County of Inner Mongolia, China. The fossil bed is CallovianOxfordian (latest Middle-earliest Late Jurassic) in age.

Description.-Specimen STMN48-1807 (Fig. 2): Forewings length $\sim 11.6 \mathrm{~mm}$ long, width as preserved $\sim 4.2 \mathrm{~mm}$. Costal margin slightly arched. Apical margin rounded. Costal area punctate, long and narrow, with length/width ratio $~ 6.0$. Apices of costal area and clavus almost at the same level, at $\sim 0.75$ of wing length. Basal cell long, about one-quarter as long as forewing length. Apical cells six. $\mathrm{Pc}+\mathrm{CP}$ long and thicken, almost parallel to costal margin. $\mathrm{ScP}$ weak and short, running to and fusing with $\mathrm{R}+\mathrm{M}+\mathrm{CuA}$ at $\sim 0.2$ of wing length, separating from the latter and then ending at apex of costal area. $\mathrm{ScP}+\mathrm{R}+\mathrm{M}+\mathrm{CuA}$ bifurcating into $\mathrm{ScP}+\mathrm{R}+\mathrm{M}$ and $\mathrm{CuA}$ at junction with crossvein cua-cup, near basal quarter of wing length; stem $\mathrm{ScP}+\mathrm{R}+\mathrm{M}$ extremely short. $\mathrm{ScP}+\mathrm{RA} \sim 1.5$ times as long as stem $\mathrm{ScP}+\mathrm{R} ; \mathrm{R}$ bifurcating into RA and $\mathrm{RP}$ in basal 0.45 wing length; RA and RP unbranched, connected to each other by crossvein ir; RA slightly arched, RP strongly curved at base and then nearly straight. Crossvein $r-m$ two; basal one slightly oblique; apical one nearly vertical and connecting to RP at junction of RP and crossvein ir. Stem $M$ very long and nearly straight, branched into $\mathrm{M}_{1+2}$ and $\mathrm{M}_{3+4}$ at about basal 0.75 wing length, just distad of the apices of costal area and clavus; $\mathrm{M}_{1+2}$ and $\mathrm{M}_{3+4}$ unbranched. Crossvein im invisible; crossvein $m$-cua connecting to stem $\mathrm{M}$ instead of branch $\mathrm{M}_{1+2}$. Stem CuA strongly curved at base, and then nearly straight, branching into $\mathrm{CuA}_{1}$ and $\mathrm{CuA}_{2}$ at junction with crossvein $m$-cua, slightly basad of bifurcation of M. CuP largely destroyed, as preserved straight. $\mathrm{A}_{1}$ and $\mathrm{A}_{2}$ completely missing.

Etymology.-The species is named after Prof. Shufan Han.

Remarks.-The genus undoubtedly belongs to the family Sinoalidae on the following characteristics: costal area punctate; apical cells six; Pc + CP long and thicken, almost parallel to costal margin; ScP weak and short; RA and RP unbranched; $M$ with two terminal branches. Shufania n. gen., however, distinctly differs from all known sinoalids in having forewing with crossvein $m$-cua connecting to stem $\mathrm{M}$, bifurcation of $\mathrm{M}$ distad of apices of costal area and clavus, $\mathrm{CuA}$ branching into $\mathrm{CuA}_{1}$ and $\mathrm{CuA}$ at junction with crossvein $m$-cua, slightly basad of bifurcation of $\mathrm{M}$. In addition, the new taxon differs from Jiania Wang and Szwedo, 2012 in possessing a smaller forewing; from Sinoala Wang and Szwedo, 2012, Luanpingia Hong, 1983, and Huabeicercopis Hong, 1983 in possessing a forewing with a very short stalk $\mathrm{M}+\mathrm{R}$.

\section{Genus Jiania Wang and Szwedo in Wang Szwedo, and Zhang, 2012 \\ Jiania gracila Wang and Szwedo in Wang Szwedo, and Zhang, 2012 \\ Figure 3}

2012 Jiania gracila Wang and Szwedo in Wang et al., p. 1237, figs. 3E, 4D, 4E, 7C, 9.

2013 Jiania gracila; Li et al., p. 7, fig. 5.

Diagnosis.-Forewing 3.1-3.6 times as long as wide; C3 $\sim 1.5$ times as long as adjoining apical cell; $\mathrm{ScP}+\mathrm{R}+\mathrm{M}+\mathrm{CuA}$ bifurcating into $\mathrm{ScP}+\mathrm{R}+\mathrm{M}$ and $\mathrm{CuA}$ at junction with crossvein cua-cup, near basal one-fifth wing length; stalk $\mathrm{ScP}+\mathrm{R}+\mathrm{M}$ present, extremely short. Hind wing with distal part darkly stained; $\mathrm{R}$ bifurcating into RA and RP at base of ending point of $\mathrm{A}_{2} ; \mathrm{CuA}$ and $\mathrm{CuA}_{1}$ at $145^{\circ}$ angle; $\mathrm{CuA}$ and $\mathrm{CuA}_{2}$ in alignment.

Materials.-STMN48-1808, female, adult in dorsoventral aspect with wings preserved at the top of the body, head missing; STMN48-1809, female, adult in dorsoventral aspect with wings preserved at the top of the body, nearly complete. 

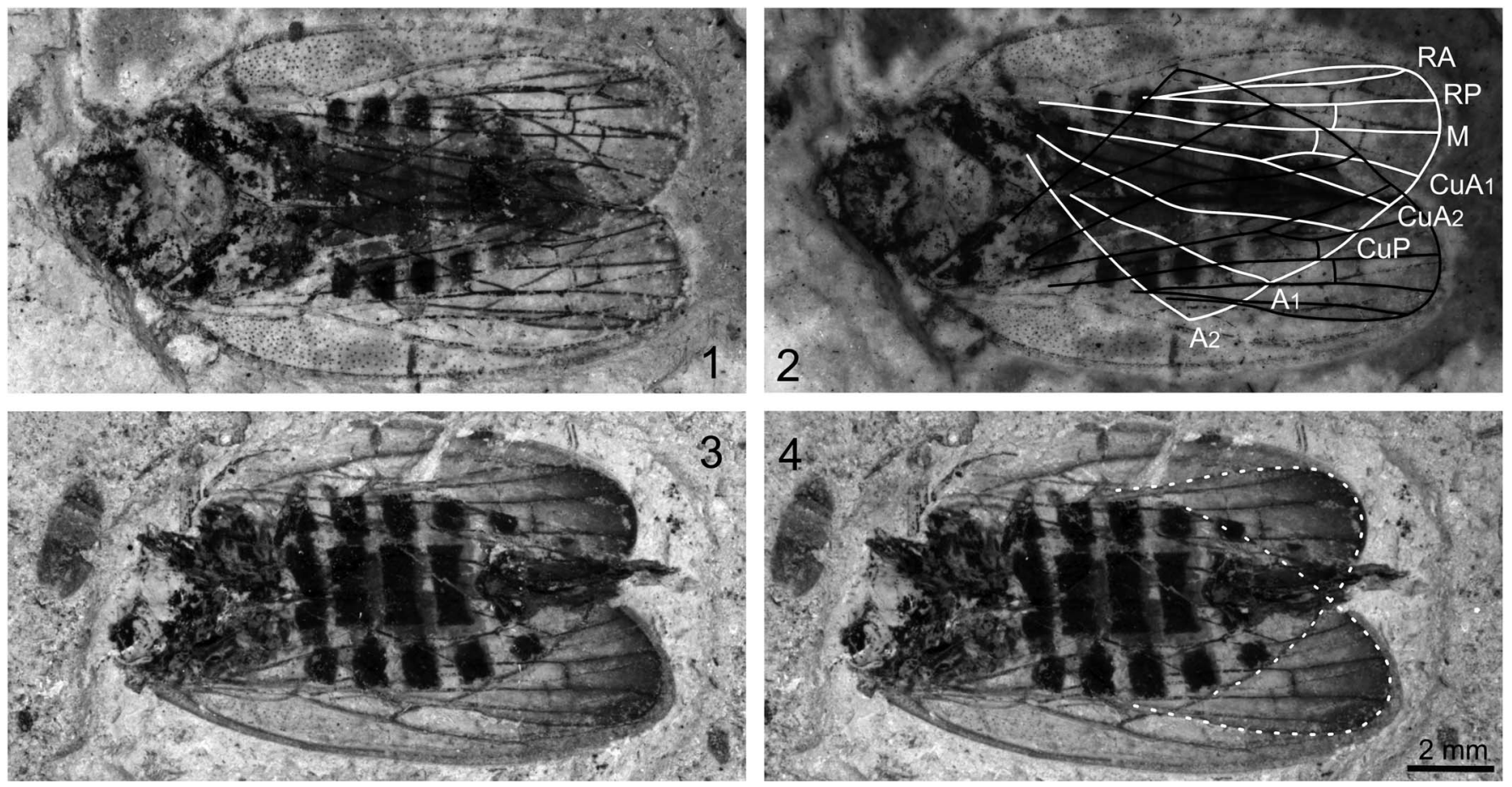

Figure 3. Jiania gracila Wang and Szwedo in Wang et al., 2012: (1) specimen STMN48-1809; (2) specimen STMN48-1809 under alcohol, with line drawings of hind wings; (3) specimen STMN48-1808; (4) specimen STMN48-1808 with outline of hind wings. Scale bar for all images.

Occurrence.-The two specimens were collected from Daohugou Village $\left(41^{\circ} 18^{\prime} \mathrm{N}, 119^{\circ} 13^{\prime} \mathrm{E}\right)$, at the same locality where the holotype was collected.

Description.-Specimen STMN48-1809 (Fig. 3.1, 3.2): body $15.2 \mathrm{~mm}$ long including forewings in repose. Head with compound eyes length as preserved $1.5 \mathrm{~mm}$, obviously narrower than pronotum. Pronotum $\sim 1.6 \mathrm{~mm}$ long and $3.5 \mathrm{~mm}$ wide, anterior margin straight, posterior margin poorly preserved. Mesonotum $\sim 3.1 \mathrm{~mm}$ long in midline and $\sim 4.0 \mathrm{~mm}$ wide at base. Abdomen with ovipositor $\sim 8.3 \mathrm{~mm}$ long and $\sim 4.7 \mathrm{~mm}$ wide, with seven segments visible. Ovipositor slightly extending beyond forewing tips.

Forewings slender, $\sim 13.0 \mathrm{~mm}$ long, $4.2 \mathrm{~mm}$ wide, with length/width ratio $\sim 3.1$. Costal margin slightly arched. Posterior margin almost straight. Apical margin rounded. Costal area punctate, long and narrow, with length/width ratio $\sim 6.0$. Clavus strongly arched, long, with length/width ratio $~ 5.2$. Apices of costal area and clavus almost at the same level, at $\sim 0.7$ of wing length. Apical cells six. $\mathrm{Pc}+\mathrm{CP}$ long and thicken, almost parallel to costal margin. ScP weak and short, running to and fusing with $\mathrm{ScP}+\mathrm{R}+\mathrm{M}+\mathrm{CuA}$, separating from the latter and then ending at apex of costal area. $\mathrm{ScP}+\mathrm{R}+\mathrm{M}+\mathrm{CuA}$ bifurcating into $\mathrm{ScP}+\mathrm{R}+\mathrm{M}$ and $\mathrm{CuA}$ at junction with crossvein сиа-сup, near basal one-fifth wing length; stem $\mathrm{ScP}+\mathrm{R}+\mathrm{M}$ extremely short. R bifurcating into RA and RP in basal 0.4 wing length; RA and RP unbranched, connected to each other by crossvein ir; RA slightly arched, RP sinuous and curved at junction with crossvein $i r$ and $r-m$. Stem $\mathrm{M}$ nearly straight, branched into $\mathrm{M}_{1+2}$ and $\mathrm{M}_{3+4}$ slightly distad of middle of wing (at about basal 0.55 wing length); $\mathrm{M}_{1+2}$ and $\mathrm{M}_{3+4}$ unbranched, connected to each other by crossvein im. Cell C3 1.5 times as long as adjoining apical cell. Stem $\mathrm{CuA}$ strongly curved at base, and then nearly straight, branching into $\mathrm{CuA}_{1}$ and $\mathrm{CuA}_{2}$ at basal 0.68 wing length. $\mathrm{CuP}$ strongly curved at junction with crossvein cua-cup, and then nearly straight. $\mathrm{A}_{1}$ and $\mathrm{A}_{2}$ poorly preserved.

Hind wing slightly shorter than forewing, with distal portion darkly stained, without peripheric membrane. Stem $\mathrm{R}$ bifurcating RA and RP at base of ending point of $\mathrm{A}_{2}$. Vein $\mathrm{M}$ unbranched, nearly straight, connected to RP by short crossvein $r-m$. Stem CuA straight, branching into $\mathrm{CuA}_{1}$ and $\mathrm{CuA}_{2}$ nearly at the same level of ending point of $\mathrm{A}_{1} ; \mathrm{CuA}$ and $\mathrm{CuA}_{1}$ at $145^{\circ}$ angle; $\mathrm{CuA}$ and $\mathrm{CuA}_{2}$ in alignment; $\mathrm{CuA}_{1}$ connected to $\mathrm{M}$ by short crossvein $m$-cua, at base of crossvein $r-m$. CuP strongly curved at the same level of ending point of $\mathrm{A}_{2}$.

Specimen STMN48-1808 (Fig. 3.3, 3.4): body with ovipositor as preserved $15.2 \mathrm{~mm}$ long. Head destroyed. Legs poorly preserved, obscure. Abdomen with ovipositor $\sim 9.8 \mathrm{~mm}$ long and $\sim 4.8 \mathrm{~mm}$ wide, with seven segments visible. Ovipositor extending just beyond forewing tips.

Forewings slender, $\sim 13.3 \mathrm{~mm}$ long, $4.1 \mathrm{~mm}$ wide, with length/width ratio $\sim 3.2$. Basal portion of forewings deformed, basal portion of left forewing partly missing. Costal margin slightly arched. Posterior margin almost straight. Apical margin rounded. Costal area long and narrow; costal area of right forewing punctate at basal part, but not visible for left one. Clavus strongly deformed. Apices of costal area and clavus almost at the same level. Apical cells six. $\mathrm{Pc}+\mathrm{CP}$ long and thicken, almost parallel to costal margin. ScP weak and short, 


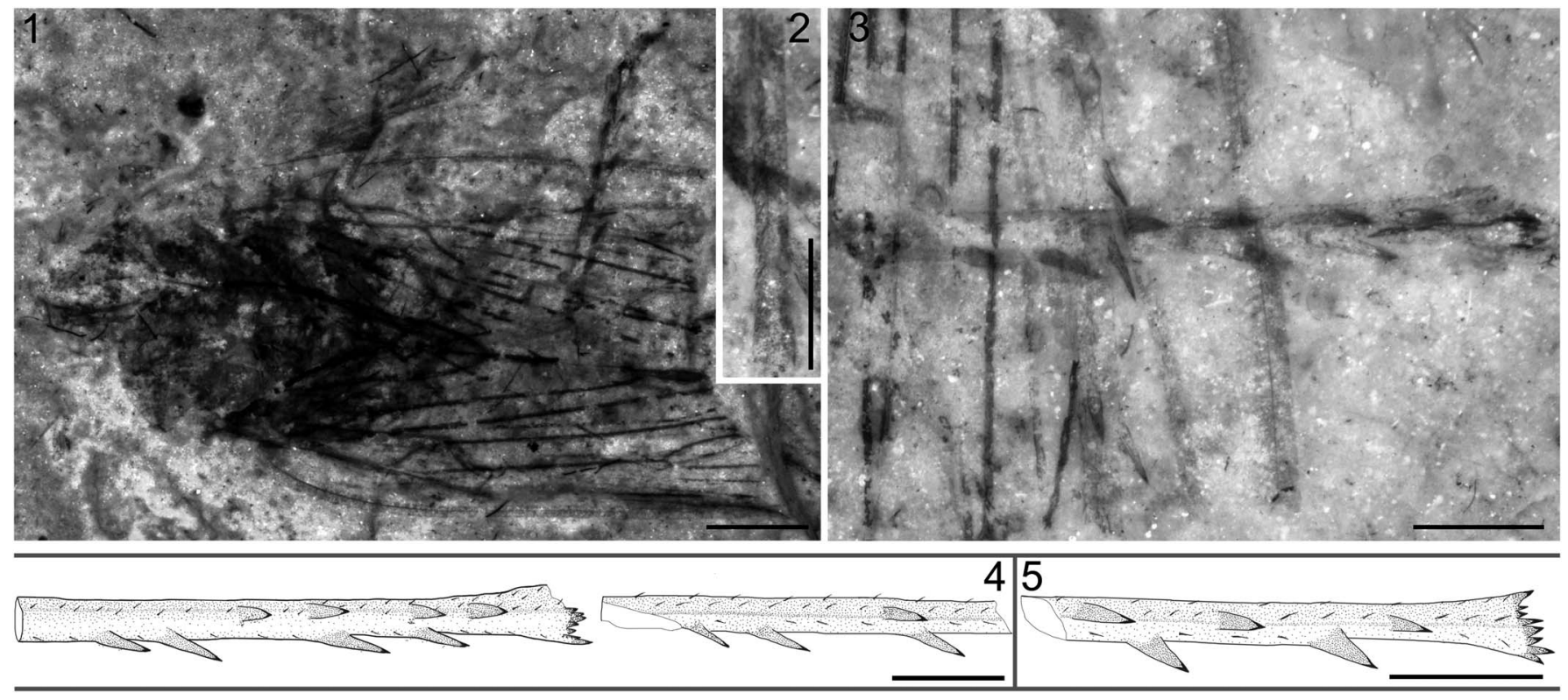

Figure 4. Jiania sp. STMN48-1810 and reconstructions of hind tibiae of Jiania Wang and Szwedo in Wang et al., 2012: (1) Jiania sp. STMN48-1810, under alcohol; (2) enlarged fore tibiae of Jiania sp. STMN48-1810, under alcohol; (3) enlarged hind tibiae of Jiania sp. STMN48-1810, under alcohol; (4) reconstructions of hind tibiae of Jiania sp. STMN48-1810; (5) reconstruction of hind tibia of Jiania crebra Wang and Szwedo in Wang et al., 2012, specimen NIGP154599. Scale $=2 \mathrm{~mm}(\mathbf{1})$ or $1 \mathrm{~mm}(\mathbf{2}-\mathbf{5})$

running to and fusing with $\mathrm{ScP}+\mathrm{R}+\mathrm{M}+\mathrm{CuA}$, separating from the latter and then ending at apex of costal area. $\mathrm{ScP}+\mathrm{R}+\mathrm{M}+$ $\mathrm{CuA}$ bifurcating into $\mathrm{ScP}+\mathrm{R}+\mathrm{M}$ and $\mathrm{CuA}$ at junction with crossvein cua-cup; stem $\mathrm{ScP}+\mathrm{R}+\mathrm{M}$ extremely short. RA and $\mathrm{RP}$ unbranched, connected to each other by crossvein ir; RA slightly arched. Stem $\mathrm{M}$ two-branched; $\mathrm{M}_{1+2}$ and $\mathrm{M}_{3+4}$ connected to each other by crossvein im. Cell C3 1.5 times as long as adjoining apical cell. Stem $\mathrm{CuA}$ branching into $\mathrm{CuA}_{1}$ and $\mathrm{CuA}_{2}$ just basad of apices of costal area and clavus. $\mathrm{CuP}$, $A_{1}$, and $A_{2}$ obscure.

Hind wing slightly shorter than forewing, with distal portion obviously darkly stained, without peripheric membrane. RA and RP nearly straight. Vein M unbranched, nearly straight, connected to RP by short crossvein $r-m$. Stem $\mathrm{CuA}$ straight; $\mathrm{CuA}$ and $\mathrm{CuA}_{1}$ at $145^{\circ}$ angle; $\mathrm{CuA}$ and $\mathrm{CuA}_{2}$ in alignment; $\mathrm{CuA}_{1}$ connected to $\mathrm{M}$ by short crossvein $m$-cua, at base of crossvein $r-m ; \mathrm{CuA}_{1}$ slightly longer than $\mathrm{CuA}_{2}$. Veins $\mathrm{CuP}, \mathrm{A}_{1}$, and $\mathrm{A}_{2}$ obscure.

Remarks.-The two new specimens are attributed to the genus Jiania Wang and Szwedo in Wang et al., 2012, based on the following diagnostic characters of the forewing: apical margin rounded, $\mathrm{ScP}+\mathrm{R}+\mathrm{M}+\mathrm{CuA}$ bifurcating into $\mathrm{ScP}+\mathrm{R}+\mathrm{M}$ and $\mathrm{CuA}$ near basal one-fifth wing length, stalk $M+R$ present, and bifurcation of $M$ distad of ending point of $A_{1}$ and basad of bifurcation of $\mathrm{CuA}$. The new specimens are assigned to Jiania gracila Wang and Szwedo in Wang et al., 2012 based on their long ovipositor extending slightly beyond forewing tips and forewing with cell C3 1.5 times as long as adjoining apical cell (versus ovipositor distinctly exceeding tip of forewing and forewing with cell C3 almost as long as adjoining apical cell in Jiania crebra Wang and Szwedo in Wang et al., 2012).
Although most morphological characters of the body structures and forewings are similar, the two specimens described herein are different from the holotype in the size, length/width ratio, and surface ornament of the costal area and clavus of the forewing. Recently, some studies based on abundant specimens demonstrated that the obvious variation in size of body and wings and length/width ratio of forewing occurs intraspecifically in fossil froghoppers (Wang and Zhang, 2009; Wang et al., 2012; Li et al., 2013; Chen et al., 2015a, b). Therefore, it is reasonable to consider the variation between the holotype and the two new specimens to be intraspecific. Forewing with clavus and basal costal area punctate is treated as important diagnostic character for Jiania gracila Wang and Szwedo in Wang et al., 2012 (Wang et al., 2012). In the new specimen STMN48-1809, both forewings possess costal areas that are entirely punctate, but clavus with puncta invisible. In STMN48-1808, puncta are only preserved on basal part of costal area of right wing. Tiny puncta are also poorly preserved or even completely missing for some sinoalid specimens reported in Wang et al. (2012). The location of puncta on the forewing might be variable for different sinoalids, but considering taphonomical and preserving factors, it is imprudent to identify taxa based on this single character.

Jiania sp.

Figure 4.1-4.4

Materials.-STMN48-1810, sex unknown, adult in dorsoventral aspect with wings preserved at the top of the body, middle and distal portion of wings destroyed.

Occurrence.-This specimen was collected from Daohugou Village $\left(41^{\circ} 18^{\prime} \mathrm{N}, 119^{\circ} 13^{\prime} \mathrm{E}\right)$, Shantou Township, Ningcheng 
County of Inner Mongolia. The fossil bed is CallovianOxfordian (latest Middle-earliest Late Jurassic) in age.

Description.-Specimen STMN48-1810 (Fig. 4.1-4.4): head partly preserved. Compound eyes missing. Rostrum extending to hind coxae. Antennae length as preserved $\sim 0.6 \mathrm{~mm}$; flagellum filiform, with segments invisible. Pronotum partly destroyed, $\sim 1.7 \mathrm{~mm}$ long. Mesonotum $\sim 3.1 \mathrm{~mm}$ long in midline and $\sim 3.5 \mathrm{~mm}$ wide at base. Fore femur strong, basal part invisible, $\sim 0.6 \mathrm{~mm}$ wide; fore tibia $\sim 2.5 \mathrm{~mm}$ long, setose, with distinct ridges; fore tarsus $\sim 1.4 \mathrm{~mm}$ long; basitarsomere very short; apical tarsomere slightly longer than mid tarsomere; two claws visible. One middle leg preserved; middle femur slightly slenderer than fore femur; middle tibia shorter than fore tibia, setose, with distinct ridges; middle tarsus obscure; tarsal claws distinct. One hind leg nearly completely preserved, other one with tarsus and apical part of tibia missing; hind femur nearly as long as fore femur; hind tibia slender, $\sim 3.7 \mathrm{~mm}$ long, with two rows of lateral spines (each row with four spines for the complete tibia, but only one and three for the tibia with apical part missing) and a row of apical teeth; basitarsomere as long as mid tarsomere, apical tarsomere and claws destroyed. Abdomen invisible.

Forewings with middle and distal part missing, length as preserved $8.9 \mathrm{~mm}$; one forewing obviously deformed. Costal margin slightly arched. Posterior margin as preserved almost straight. Costal area and clavus arched, long and narrow. $\mathrm{Pc}+\mathrm{CP}$ long, almost parallel to costal margin. ScP weak and short, running to and fusing with $\mathrm{ScP}+\mathrm{R}+\mathrm{M}+\mathrm{CuA}$. $\mathrm{ScP}+\mathrm{R}+$ $\mathrm{M}+\mathrm{CuA}$, bifurcating into $\mathrm{ScP}+\mathrm{R}+\mathrm{M}$ and $\mathrm{CuA}$ nearly at junction with crossvein cua-cup; stem $\mathrm{ScP}+\mathrm{R}+\mathrm{M}$ extremely short. Stem $M$ nearly straight as preserved; branching into $M_{1+2}$ and $\mathrm{M}_{3+4}$ basad of bifurcation of $\mathrm{CuA}$ and distad of ending point of $\mathrm{A}_{1}$. Stem $\mathrm{CuA}$ strongly curved at base, and then nearly straight as preserved. CuP strongly curved at junction with crossvein cua-cup, and then nearly straight. $\mathrm{A}_{1}$ nearly straight and $A_{2}$ slightly sinuous. Hind wing obscure.

Remarks.-This specimen undoubtedly belongs to the family Sinoalidae based on its body structures and unique forewing with $\mathrm{Pc}+\mathrm{CP}$ long, almost parallel to costal margin, $\mathrm{ScP}$ weak and short, and $\mathrm{R}, \mathrm{M}$ and $\mathrm{CuA}$ divided from stem $\mathrm{ScP}+\mathrm{R}+$ $\mathrm{M}+\mathrm{CuA}$ very closely. We placed the new specimen in the genus Jiania Wang and Szwedo in Wang et al., 2012 based on the following venational characters of forewings: short stalk $\mathrm{ScP}+\mathrm{R}+\mathrm{M}$ existing (vs. short stalk $\mathrm{M}+\mathrm{CuA}$ existing in Sinoala Wang and Szwedo, 2012 and R, M, CuA separated from stem $\mathrm{ScP}+\mathrm{R}+\mathrm{M}+\mathrm{CuA}$ at the same point in Luanpingia Hong, 1983 and Huabeicercopis Hong, 1983) and M branching into $\mathrm{M}_{1+2}$ and $\mathrm{M}_{3+4}$ basad of bifurcation of $\mathrm{CuA}$ and distad of ending point of $A_{1}$ (versus $M$ branching into $M_{1+2}$ and $M_{3+4}$ basad of ending point of $A_{1}$ in Sinoala Wang and Szwedo, 2012 and $M$ branching into $\mathrm{M}_{1+2}$ and $\mathrm{M}_{3+4}$ just distad of bifurcation of $\mathrm{CuA}$ in Shufania n. gen.). However, due to incomplete preservation and somewhat deformation of the specimen, it is impossible to get more specific characters to compare it with the other two congeneric species in detail. Therefore, we herein maintain the specimen in open nomenclature in the genus Jiania Wang and Szwedo, 2012.

\section{Discussion}

The Sinoalidae, with six known genera, is known so far only from the Middle to earliest Late Jurassic of northeastern China (Wang et al., 2012; this study). The new genus reported in the present study is distinct from all other genera in forewing venations, leading to the necessity to revise the family Sinoalidae. Bifurcation of vein $\mathrm{M}$ basad of bifurcation of $\mathrm{CuA}$ on forewing is considered as one of the important diagnostic characters for the Sinoalidae, differing from the con-superfamilial Procercopidae. However, Shufania n. gen. possesses a forewing with bifurcation of vein $\mathrm{M}$ apparently distad of bifurcation of CuA. Chen et al. (2015b) erected a new species, Anthoscytina elegans, based on ten well-preserved procercopid fossils collected from the Daohugou Biota. These specimens show high intraspecific variation on relative branching position of $\mathrm{M}$ and $\mathrm{CuA}$. Therefore, this venational character, unstable even at species level for the Cercopoidea, is not appropriate for family-level diagnosis.

Up to now, only two sinoalid species with information on hind wings have been reported (Hong, 1983; Wang et al., 2012). Wang et al. (2012) established Sinoala parallelivena based on several fossils from the latest Middle-earliest Late Jurassic of Inner Mongolia, China, including information of body structures, forewings, and hind wings. Hong (1983) erected Hebeicercopis triangulata based on an almost completely isolated hind wing and Huabeicercopis yangi mainly based on forewings from the Middle Jurassic of Heibei, China. Wang et al. (2012) considered that these two taxa might be synonymous because of the corresponding size and the same original horizon and locality. We herein report two new imprint fossils of Jiania gracila with some interesting information about sinoalid hind wings. Although the forewings of the genera Huabeicercopis, Sinoala, and Jiania are significantly different (see Wang et al., 2012), the venations of the three sinoalid hind wings are obviously less variable, which is expected because the venations of sinoalid hind wings are very simplified in topology and obviously reduced in branches of longitudinal veins.

Hind wings with distal portion obviously darkly stained are well preserved for STMN48-1808, and visible for STMN481809 and most of the reported Jiania fossils (Fig. 3; Wang et al., 2012). However, this color pattern is completely absent for the seven well-preserved Sinoala fossils in Wang et al. (2012), so hind wings of this genus are likely colorless and transparent. Color patterns of hind wings are likely variable for different sinoalid froghoppers. However, wing color pattern is easily weakened or even erased by diagenetic processes for imprint fossils, so the morphological character is not reliable to distinguish sinoalids, as is the case for other fossil cicadomorphs (e.g., Chen et al., 2016).

Modern taxa of the Cercopoidea possess hind tibia with one row of immobile spines (1-6, commonly 2) (Wang et al., 2012). Some studies based on abundant whole-body fossils suggest 
that the Procercopidae (Shcherbakov and Popov, 2002) likely just has one single spine (Shcherbakov, 1988; Wang and Zhang, 2009; Li et al., 2013; D. Chen et al., 2015; Chen et al., 2015a). The Sinoalidae differs from the Procercopidae and modern Cercopoidea in having hind tibia with two rows of spines laterally (Fig. 4.4, 4.5; at most four for each row, as shown in the new specimen STMN48-1810). The left and right hind tibiae preserved in STMN48-1810 suggest that lateral spines might be different in number and/or position (Fig. 4.4). Lateral spines (4-6 in number) on the hind tibia of the living aphrophorid Sinophora Melichar, 1902 (Anufriev, 1972; Liang, 1990) are sometimes variable in number for the same species or even the same individuals (Chou et al., 1986; Wang et al., 2012). STMN48-1810 indicates that the number of spines of the hind tibia might be also different intra-individually within the Sinoalidae, or at least their relative position is variable.

\section{Acknowledgments}

The authors are extremely grateful to B. Wang and H. Zhang for their constructive comments on an earlier version of the manuscript. The present study was supported by grants from the National Natural Science Foundation of China (41502007), the Natural Scientific Foundation of Shandong Province (ZR2013DQ017), and China Postdoctoral Science Foundation (2015M580480). Many thanks go to two editors, J. Jin and J. Hannibal, and two reviewers, A. Nel and J. Szwedo, who provided many constructive comments, which undoubtedly improved this manuscript.

\section{References}

Amyot, C.J.B., and Serville, J.G.A., 1843, Deuxième partie. Homoptères Homoptera Latr. Histoire Naturelle des Insectes: Hemiptères: Paris, Librairie encyclopédique de Roret, v. 1843, 676 p.

Anufriev, G.A., 1972, Revision of froghoppers from the genus Sinophora Melichar, 1902 (Homoptera, Aphrophoridae): Journal of Natural History, v. 6 , p. $385-394$.

Chen, D., Yao, Y., and Ren, D., 2015, A new species of fossil Procercopidae (Hemiptera, Cicadomorpha) from the Lower Cretaceous of Northeastern China: Cretaceous Research, v. 52, p. 402-406.

Chen, J., Wang, B., Engel, M.S., Wappler, T., Jarzembowski, E.A., Zhang, H., Wang, X., Zheng, X., and Rust, J., 2014, Extreme adaptations for aquatic ectoparasitism in a Jurassic fly larva: eLife, v. 3, p. e02844.

Chen, J., Wang, B., Zhang, H., Wang, X., and Zheng, X., 2015a, New fossil Procercopidae (Hemiptera: Cicadomorpha) from the Middle Jurassic of Daohugou, Inner Mongolia, China: European Journal of Entomology, v. 112 , p. 373-380.

Chen, J., Zhang, H., Wang, B., Zheng, X., and Wang, X., 2015b, High variability in tegminal venation of primitive cercopoids (Insecta, Hemiptera), as implied by the new discovery of fossils from the Middle Jurassic of China: Entomological Science, v. 18, p. 147-152.

Chen, J., Zhang, H., Wang, B., Zheng, Y., Wang, X., and Zheng, X., 2016, New Jurassic tettigarctid cicadas from China with a novel example of disruptive coloration: Acta Palaeontologica Polonica, v. 61, p. 853-862.

Chou, I., Yuan, F., and Liang, A., 1986, The systematics and phylogeny of the genus Sinophara Melichar (Homoptera: Aphrophoridae): Entomotaxonomia, v. 8, p. 97-120. [in Chinese, with English summary]

Cohen, K.M., Harper, D.A.T., and Gibbard, P.L., 2016, International Chronostratigraphic Chart http://stratigraphy.org/ICSchart/ChronostratChart201612.jpg

Dietrich, C.H., 2002, Evolution of Cicadomorpha (Insecta, Hemiptera): Denisia, v. 4 , p. $155-170$.

Dietrich, C.H., 2005, Keys to the families of Cicadomorpha and subfamilies and tribes of Cicadellidae (Hemiptera: Auchenorrhyncha): Florida Entomologist, v. 88 , p. $502-517$.
Dohrn, F.A., 1859, Homoptera. Catalogus Hemipterorum: Entomologischen Verein zu Stettin, v. 1859, p. 1-102.

Evans, J.W., 1946, A natural classification of leaf-hoppers (Homoptera, Jassoidea). Part 1. External morphology and systematic position: Transactions of the Royal Entomological Society of London, v. 96, p. 47-60.

Hamilton, K.G.A., 1990, Chapter 6. Homoptera, in Grimaldi, D.A., ed., Insects from the Santana Formation, Lower Cretaceous of Brazil: Bulletin of the American Museum of Natural History, v. 195, p. 82-122.

Hamilton, K.G.A., 2001, A new family of froghoppers from the American tropics (Hemiptera: Cercopoidea: Epipygidae): Biodiversity, v. 2, p. 15-21.

Hamilton, K.G.A., 2012, Spittlebugs of new-world Aphrophorinae, part 1: Ptyelini (Hemiptera, Cercopoidea): Zootaxa, v. 3497, p. 41-59.

Holzinger, W.E., Kammerlander, I., and Nickel, H., 2003, The Auchenorrhyncha of Central Europe. Vol. 1: Fulgoromorpha, Cicadomorpha excl. Cicadellidae: Leiden, Brill, 673 p.

Hong, Y., 1983, Middle Jurassic Fossil Insects in North China: Beijing, Geological Publishing House, 187 p. [in Chinese, with English summary]

Leach, W.E., 1815, Entomology, in Brewster, D., ed., The Edinburgh Encyclopaedia, v. 9, p. 57-172.

Li, S., Shih, C., Wang, C., Pang, H., and Ren, D., 2013, Forever love: the hitherto earliest record of copulating insects from the Middle Jurassic of China: PLoS ONE, v. 8, p. e78188.

Liang, A., 1990, A new species of Sinophora Melichar (Homoptera: Aphrophoridae) from Xizang, China: Acta Entomologica Sinica, v. 33, p. 89-91. [in Chinese, with English summary]

Linnaeus, C., 1758, Systema natura per regna tria naturae secundum classes, ordines, genera, species, cum characteribus, differentiis, synonymis, locis, Tenth edition: Holmiae, Laurentius Salvius, $824 \mathrm{p}$.

Liu, Y., Liu, Y., and Zhang, H., 2006, LA-ICPMS zircon U-Pb dating in the Jurassic Daohugou Beds and correlative strata in Ningcheng of Inner Mongolia: Acta Geologica Sinica (English Edition), v. 80, p. $733-742$.

Liu, Y., Kuang, H., Jiang, X., Peng, N., Xu, H., and Sun, H., 2012, Timing of the earliest known feathered dinosaurs and transitional pterosaurs older than the Jehol Biota: Palaeogeography, Palaeoclimatology, Palaeoecology, v. $323-325$, p. $1-12$.

Nel, A., Prokop, J., Nel, P., Grandcolas, P., Huang, D., Roques, P., Guilbert, E., Dostal, O., and Szwedo, J., 2012, Traits and evolution of wing venation pattern in paraneopteran insects: Journal of Morphology, v. 273, p. $480-506$.

Rasnitsyn, A.P., Zhang, H., and Wang, B., 2006, Bizarre fossil insects, the webspinning sawflies of the genus Ferganolyda (Vespida, Pamphilioidea) from the Middle Jurassic of Daohugou, Inner Mongolia, China: Palaeontology, v. 49, p. 907-916.

Shcherbakov, D.E., 1988, New cicadas (Cicadina) from the later Mesozoic of Transbaikalia: Paleontological Journal, v. 4, p. 52-63.

Shcherbakov, D.E., and Popov, Y.A., 2002, Superorder Cimicidea Laicharting, 1781 order Hemiptera Linné, 1758. The bugs, cicadas, plantlice, scale insects, etc., in Rasnitsyn, A.P., and Quicke, D.L.J., eds., History of Insects: Dordrecht, Kluwer, p. 152-155.

Stål, C., 1866, Hemiptera Homoptera Latr: Hemiptera Africana, v. 4, p. 1-276

Wang, B., 2009, Mesozoic Hemiptera and Coleoptera (Insecta) from Northeastern China: Taxonomy, Evolution, and Taphonomy: Nanjing, Nanjing Institute of Geology and Palaeontology, Chinese Academy of Sciences, 320 p. [in Chinese, with English summary]

Wang, B., and Zhang, H., 2009, A remarkable new genus of Procercopidae (Hemiptera: Cercopoidea) from the Middle Jurassic of China: Comptes Rendus Palevol, v. 8, p. 389-394.

Wang, B., and Zhang, H., 2011, The Oldest Tenebrionoidea (Coleoptera) from the Middle Jurassic of China: Journal of Paleontology, v. 85, p. $266-270$.

Wang, B., Szwedo, J., and Zhang, H., 2012, New Jurassic Cercopoidea from China and their evolutionary significance (Insecta: Hemiptera): Palaeontology, v. 55, p. 1223-1243.

Wang, B., Zhang, H., Jarzembowski, E.A., Fang, Y., and Zheng, D., 2013 , Taphonomic variability of fossil insects: a biostratinomic study of Palaeontinidae and Tettigarctidae (Insecta: Hemiptera) from the Jurassic Daohugou Lagerstätte: Palaios, v. 28, p. 233-242.

Wang, L., Hu, D., Zhang, L., Zhang, S., He, H., Deng, C., Wang, X., Zhou, Z., and Zhu, R., 2013, SIMS U-Pb zircon age of Jurassic sediments in Linglongta, Jianchang, western Liaoning: constraint on the age of oldest feathered dinosaurs: Chinese Science Bulletin, v. 58, p. 1346-1353.

Yan, E.V., Wang, B., Ponomarenko, A.G., and Zhang, H., 2014, The most mysterious beetles: Jurassic Jurodidae (Insecta: Coleoptera) from northern China: Gondwana Research, v. 25, p. 214-225.

Accepted 13 April 2017 